\title{
The Role of Circulation Services In the Major University Library
}

A survey of 103 major academic libraries examined the professional/ nonprofessional functions, staffing patterns, changes, and management attitudes towards circulation departments. Five tables present numerical data, and an extended summary discusses questions raised by conclusions from the data.

\begin{abstract}
A DEPARTMENT of the major university library has received wide attention in recent years, as has the application of systems analysis to circulation routines. Yet concurrently, rationale governing the allocation of functions and staff to this area has received virtually no published attention. The library administrator looking for a body of accepted practice as a theoretical framework for planning finds that none exists. Although assumptions are commonly made about the role of circulation services and its changes over the past few decades, these assumptions often bear little relationship with current practice. The issue is a major one in view of the importance of circulation to the logistics of library operation, and because of the substantial staff commitment involved.

The present study was initiated to discover (1) the role of the circulation department in the major university library and the extent to which it has changed; (2) current staffing patterns and their relation to function; (3) the validity of some assumed factors as causal influences; and (4) management attitudes toward the role of this area.
\end{abstract}

Dr. Miller is director of library services, California State College, California, Pennsylvania.

\section{SURVEY OF THE LITERATURE}

An exhaustive survey of library literature since 1900 was first conducted to discover past and present attitudes toward circulation services. This was extended to the literature of library management and then to classical management theory, from which much library management theory is derived. In addition, a survey was conducted of circulation department function and staffing patterns in 126 university libraries, which ultimately led to an examination of the relationship between current function and staffing patterns with management attitudes toward these factors.

The professional literature during the past half century reveals no consensus on the role of the circulation department. The 1926 ALA Survey of Libraries in the United States reported a close relationship between the circulation and reference departments and noted that much circulation work concerned study and research functions. ${ }^{1}$ The $1933 \mathrm{Cir}$ culation Work in College and University Libraries by Brown and Bousfield, the classic and most comprehensive work to date on the circulation department, defined its role to include the technical function of collection control and circulation, as well as the location of information and material by individual 
readers, library instruction, use of the card catalog, reader's advisory service, and instructional development. ${ }^{2}$ Donald Coney, however, in his review of this comprehensive view of the circulation department, stated that it was "founded on a definition that extends college circulation work beyond the limits usually understood," and noted the disparate skills required for book delivery as compared to instructional functions. ${ }^{3}$ Successive editions of standard library administration texts by Lyle and Wilson and Tauber reflect a narrowing of the circulation function, but do not indicate evolution to a completely technical status. The July 1957 issue of Library Trends served to emphasize the lack of consensus on the circulation function, whereas Wasserman and Bundy indicated that technical assistants frequently serve as library department heads, primarily in circulation. ${ }^{4}$

Many detailed library position classifications have been developed. Although those preceding and including the 1947 statement of the ALA Board on Salaries, Staff, and Tenure did not embrace the comprehensive Brown and Bousfield concept of circulation work, they did recommend widespread employment of professionals in head and subordinate positions. Yet the 1948 ALA Descriptive List of Professianal Duties in Libraries, concluded that ". . . registration and circulation is non-professional in nature, requiring first of all, familiarity with good clerical procedures"; the work would be conducted by clerical staffs in larger libraries with intermittent professional supervision. ${ }^{5}$ Current statements, although shifting substantially from the pre-1948 era, are not as detailed nor as influential as earlier pronouncements, nor do they relate function to staff.

In general, the library literature has reflected the classic management school (with early appreciation for the writings of Fayol). Such literature, together with general management publications, has emphasized the separation and rationalization of unrelated functions calling for different skills, and the grouping within departments and positions of functions homogeneous in nature and consistent in staff requirements. Writers such as Coney and Howard within librarianship, and within management, Fayol, Mooney and Reiley, and Ralph C. Davis, by implication argue for a department specializing in technical functions as a single-purpose organization. ${ }^{6}$

The literature survey left unanswered the following questions: (1) What functions are most commonly allocated to the circulation department? (2) What is the level of staff commonly assigned? (3) Specifically, to what extent are professionals employed? (4) Do staffing patterns appear to be appropriately related to functions? (5) What is management's conception of the circulation department role? (6) What, if any, patterns emerge in comparing present functions in individual libraries and the use of computerized routines and/or systems analysis in the circulation department?

\section{SURVEY METHODS}

To help answer these questions, a survey was made of 126 major university libraries, selected from those institutions in Earned Degrees Conferred graduating more than thirty Ph.D.'s per year. ${ }^{7}$ These libraries had an average of $1,173,203$ volumes and served institutions with a mean of 15,903 students. Thus these libraries were presumably affording reasonably sophisticated information service combined with high circulation.

The questionnaire was highly structured, but with major provision for atypical responses. Of the 126 libraries included in the survey, replies were received from 114, a return of 91 percent. Of these, 11 were received from libraries with decentralized circulation ser- 
TABLE 1

Quick Information Service as a Circulation Department Function

\begin{tabular}{|c|c|c|c|c|c|}
\hline & Group $1^{\circ}$ & Group $2^{\circ}$ & Group $3^{\circ}$ & Group $4^{\circ}$ & Total \\
\hline Service rendered. & 21 & 36 & 23 & 11 & 91 \\
\hline $\begin{array}{l}\text { Not provided from within the circulation } \\
\text { department. }\end{array}$ & 1 & 3 & 4 & 3 & 11 \\
\hline Degree of Service Provided: & & & & & \\
\hline $\begin{array}{l}\text { Queries requiring professional knowledge } \\
\text { for solution referred elsewhere. }\end{array}$ & 1 & & 2 & 1 & 4 \\
\hline $\begin{array}{l}\text { Questions requiring extended time } \\
\text { referred elsewhere. }\end{array}$ & & 1 & 2 & & 3 \\
\hline $\begin{array}{l}\text { Only directional and incidental } \\
\text { queries handled. }\end{array}$ & 19 & 34 & 17 & 10 & 80 \\
\hline No response. & 1 & 1 & 2 & & 4 \\
\hline
\end{tabular}

- Group 1-libraries of less than 500,000 volumes; Group 2-500,000-999,999 volumes; Group 3-1,000,0001,999,999; Group 4-2,000,000 volumes and over.

vice, which were eliminated from the study. ${ }^{8}$

Returns were analyzed in four distinct categories in order to examine the effect of size on selected variables. The four categories were the following:

Group 1. Libraries of less than

500,000 volumes $\ldots \ldots \ldots \ldots . N=25$.

Group 2. Over 500,000 but less

than one million .......... N $=42$.

Group 3. One million but less than

two million $\ldots \ldots \ldots \ldots \ldots, \mathrm{N}=30$.

Group 4. Over two million vol-

umes $\ldots \ldots \ldots \ldots \ldots \ldots, \mathrm{N}=17$.

The choice was an arbitrary one, but provided sufficient 'N's in each category to yield meaningful tabulations.

\section{Function}

The presence or absence of various functions was studied, and, at the same time, the depth of departmental participation and responsibility was examined.

1. Reserve Books. The majority of libraries allocated some degree of responsibility for the reserve function to circulation, particularly in Group 1 libraries. Only in the largest libraries were reserves generally administered separately. If the department were accorded some role, it was usually given primary responsibility.

Most reader service functions were formerly offered directly from the circulation desk. The present study shows that half of the Group 1 libraries offered reserve service from the circulation desk. This percentage uniformly decreased as the size of the library increased.

2. In-depth and/or Quick Information Service. As expected, only four libraries offered in-depth information service from circulation. On the other hand, ninety-one respondents ( 89 percent) indicated that they provided one of three categories of "quick information service" from the circulation desk. (See Table 1.)

Of ninety-one circulation departments offering in-depth information, or quick information service, 88 percent indicated that directional and incidental queries were the only ones handled. It is evident that although the circulation desk is still a source of information service in most libraries, it is limited to handling largely ephemeral requests.

3. Interlibrary Loan. Many libraries (61 percent) have allocated the interlibrary loan function outside the circulation department. However, no clear pattern exists by size of library. Of those exercising some responsibility in this area, almost half provided this service from the circulation desk and 62 percent made the department administra- 
tively responsible for this function.

4. Library Instruction. Only about a third of the libraries entrusted to the circulation department some responsibility for library instruction or orientation. When such responsibility was present, with two exceptions it was in a supportive rather than in a primary role.

5. Reader Assistance. Forty of the 103 libraries considered the assistance to readers in the use of the card catalog to be a function of the circulation department. In three cases the role was a primary one, and in the case of an additional three, the function was shared equally with the reference department. In all but four cases, this activity was performed from the circulation desk.

6. Inventory. Many circulation departments (61 percent) were entrusted with some degree of responsibility for inventory.

7. Book Selection. A traditional role of the comprehensive circulation department was book selection. The rationale was that circulation personnel had the most direct contacts with the user community and therefore were in the best position to judge requirements. Some degree of activity in this area was retained by just over half of the libraries. Of these, roughly two-thirds shared this responsibility with all or virtually all departments.

8. Shelving. Shelving and stack maintenance was a function of 85 percent of the circulation departments: 78 of 85 libraries indicated that circulation superintended this activity.

9. Policy Formation. To determine the degree of responsibility for formulation of circulation policy, a range of four responses was provided. In 81 libraries (79 percent), one, or a combination of both of the following statements describes the heavy responsibility that the department bears in policy formation: "Chief of circulation services recommends policies to immediate superior for review and adoption; Chief of Circulation Department participates in committee with representatives of other departments et al in policy formation." This role might either reflect the widespread presence of professionals, or explain their placement in the circulation department.

To summarize, the average circulation department included in this study would have primary responsibility for reserve books, although they would be circulated from a location separate from the circulation desk; would handle directional and incidental information queries but give no in-depth reference service; and would have primary responsibility for inventory of the book collection, shelving, and stack maintenance. It would play a major role in the development of circulation policy. On the other hand, it would have no responsibility for interlibrary loan, library instruction/orientation, assistance to readers at the card catalog, or in book selection other than that granted to other departments.

\section{Professional and NonProfessional Functions}

Not only is it important to determine what functions still rest with the circulation department, but also to establish the degree to which they are professional. The following functions are assumed to be essentially professional: indepth reference service; quick information service where the only questions referred elsewhere are those requiring extended time to answer; primary responsibility for interlibrary loan; a primary role in instruction and/or orientation in the use of the library; assisting readers in the use of the card catalog where the department has a major role or shares this equally with reference; book selection; and participation in policy formation.

Subprofessional or clerical functions include: 
TABLE 2

Patterns in Two Types of Professional Functions in Circulation Services: AN ANALYSIS By StZE OF LIBRARY $\left(\mathrm{N}=100^{\mathrm{a}}\right)$

\begin{tabular}{lcccrr}
\hline \hline & Group 1 & Group 2 & $\begin{array}{c}\text { Library } \\
\text { Group 3 }\end{array}$ & Group 4 & Total \\
\hline $\begin{array}{l}\text { Number of Professional Functions Present } \\
\quad \text { Requiring Special Assignment of }\end{array}$ & & & & & \\
$\quad \begin{array}{l}\text { Professional Personnel } \\
1\end{array}$ & 7 & 8 & 6 & 6 & \\
2 & 1 & 1 & 1 & & 3 \\
Total Professional Functions Present & & & & & \\
$\quad$ Including Above) & 8 & 19 & 15 & 6 & 48 \\
1 & 6 & 14 & 8 & 2 & 30 \\
2 & 7 & 3 & 2 & 6 & 18 \\
3 & 1 & 1 & 2 & & 3 \\
4 & 1 & & & & \\
5 & & & & & \\
\hline
\end{tabular}

a Three respondents did not provide sufficient information to be included in this analysis.

1. Reserve books (any degree of involvement)

2. Quick information service where queries requiring professional knowledge are referred elsewhere, or where directional and incidental queries (such as those involving library rules) are the only ones handled

3. Supportive work with interlibrary loans

4. Supportive work in library instruction where primary responsibility lies elsewhere and other professional personnel are available to work with subprofessionals within the department

5. Inventory work

6. Shelving and stack maintenance

Professional functions were further distinguished between (a) those that would probably be performed within the circulation department primarily because a professional was already available there, and (b) those that would justify the special assignment of professional staff to this department.

In the first category were placed:

1. Quick information service where only questions requiring extended time to answer are referred elsewhere.
2. Book selection where professionals of all departments participate equally (except for greater participation by acquisitions and reference).

3. Policy formation.

In the second category were placed:

1. In-depth information service.

2. Primary responsibility for interlibrary loans.

3. Primary responsibility for library instruction and/or orientation.

Where professional functions required specific professional staff assignment, only thirty ( 30 percent) of the circulation departments undertook even one of the prescribed services. Of this number, twenty-seven undertook only one service. A significant aspect of this functional pattern is that the average circulation department in the major university library undertakes no functions requiring the specific assignment of professional personnel. (See Table 2.)

Considering all functions requiring professional personnel, 48 percent of the departments embraced only one such activity-that of policy formation. In addition, 30 percent of the departments embraced two, and 18 percent undertook three. As Mooney and Reiley imply in their Principle of Functionalism, 
policy-making is easily separable from other aspects of circulation work and need not be performed within the department. ${ }^{9}$

\section{Staffing Patterns}

The purpose of the staff section of this study was to determine (1) the number and level of staff assigned to circulation services, and (2) the relationship of staff assignments to functions allocated in this area.

1. General Staff Levels. Of the 75 libraries providing complete responses, 58 had circulation departments headed by individuals with the master's degree or higher. Of these, 47 possessed the master's degree in library science. Supportive staff ranged from those possessing the doctorate (one case) to those with no formal preparation. The over-all percentage of professionals with either a master's degree in library science or a higher degree in relation to all circulation staff averaged about 13 percent with only slight variations by library size.

2. Specialized Subordinate Levels. With regard to specialized subordinate positions within the department, of the 103 libraries with centralized circulation departments, 61 had the specialized position of assistant or associate direc- tor of circulation services. Most frequently, the position was occupied by a technical assistant, as in 27 of the libraries with this position. In addition, one incumbent held the doctorate and 25 held the master's in library science.

The circulation departments of 27 libraries maintained the position of interlibrary loan librarian. In 59 percent of these libraries, the occupant held the master's degree in library science. Other staff consisted of four subject-field master's holders, nineteen technical assistants, and thirty-two clerks.

Forty libraries reported a subdepartment for reserves within circulation services. The 37 libraries reporting staff composition employed 11 professional librarians (master's in library science), supplemented by a total of 49 technical assistants and 87 clerks.

3. Staffing and Function. One of the most significant aspects of the study was the extent to which the presence of high-level staff coincided with high-level professional functions. Of 17 circulation departments employing four or more professionals in their staff, seven have no professional function requiring assignment of professionals; six embrace only one professional function of any kind-that of policy formation. Of 43 departments employing two or

TABLE 3

Professional Staff Assignments in Relation to Two Types Of Professional Functions $\left(\mathrm{N}=58^{\circ}\right)$

\begin{tabular}{|c|c|c|c|c|c|c|}
\hline & \multicolumn{3}{|c|}{ SFoo } & \multicolumn{3}{|c|}{ GF००० } \\
\hline & One & Two & None & One & Two & Three or More \\
\hline $\begin{array}{c}\text { Professionals } \\
\text { In Department }\end{array}$ & & & & & & \\
\hline $\begin{array}{l}\text { One Professional in Department } \\
\text { Two Professionals } \\
\text { Three Professionals } \\
\text { Four or More Professionals } \\
\text { No Professionals }\end{array}$ & $\begin{array}{l}3 \\
5 \\
2 \\
8 \\
3\end{array}$ & $\begin{array}{l}2 \\
1 \\
2\end{array}$ & $\begin{array}{r}19 \\
11 \\
7 \\
7 \\
13\end{array}$ & $\begin{array}{r}15 \\
7 \\
6 \\
6 \\
10\end{array}$ & $\begin{array}{l}3 \\
6 \\
3 \\
6 \\
4\end{array}$ & $\begin{array}{l}6 \\
3 \\
5 \\
3\end{array}$ \\
\hline
\end{tabular}

- Seventeen responses insufficiently complete for inclusion.

-o 'Special Function'-according to the criteria described above, these are the functions that specifically would in themselves justify and require the special assignment of professionals to the department.

○. General professional function. Although professional in nature, they are more incidental than integral to the department function and would often be assigned to the department only because professionals were available there. They would not in themselves normally justify the special assignment of professional personnel to the circulation department. 
more professionals, 19 have been allocated only a single professional function of any description, and 25 have no functions specifically requiring the assignment of professionals. (See Table 3.)

Apparently, a substantial number of professional staff are being employed in less than professional work, particularly where multiple professionals are employed in the absence of any professional functions justifying their assignment.

\section{Causes for Change}

Many casual assumptions are made for the evolution of circulation services. Undoubtedly, increases in the volume of circulation and greater sophistication in the information service rendered by libraries in this group are major factors. Such pressures have made rationalization of functions formerly grouped around the circulation desk essential. At the same time, these pressures are said to have prompted other phenomena: the introduction of automation and systems analysis, larger and more functional buildings, open stacks -thus giving the reader the opportunity of bypassing the circulation desk in his search for information, and the rise of the reader service division, which collectively embraces the functions originally grouped around the circulation desk.

Systems analysis in particular, preceding automation in this area, is said to have prompted review of departmental objectives and reallocation of functions. Sixty-four libraries had undertaken some form of computerization and 31 had extended this to the circulation department. Forty-one libraries had undertaken some form of systems analysis, $8 \mathrm{had}$ extended this to reader services as a whole, and 40 had included circulation. Yet surprisingly, 13 libraries reported that "as a result of computerization of routines, and/or systems analysis ... the range of functions allocated to the circulation department has been broadened." Two indicated that their scope had been narrowed, whereas in 43 libraries, the range had remained the same. Four libraries reported increases in the number of professionals, 6 reported reductions, and 47 institutions reported that the number of professionals had remained the same.

Architectural influences impose little or no restraint in the rationalization of circulation functions. Asked whether the scope of functions embraced in circulation would be diminished, increased, or remain the same were it not for architectural limitations, 2 reported the range would be diminished, 12 indicated that the scope would be increased, whereas the majority ( 87 percent) reported that the scope would be substantially the same. This may be partially explained by the fact that 83 libraries have either occupied new buildings or have undergone refurbishing with repositioning of the circulation department.

There is no substantial difference in the number of professional functions assigned to closed and open stack libraries. The same may be said of departments within and outside of reader service divisions.

\section{Management Attrtudes}

The final section of the study surveyed management attitudes toward the role of circulation services for which there exists a substantial community of thought. Fifty-seven percent indicated that although the circulation department is service-oriented, it is primarily concerned with technical functions; and that virtually all information service queries, other than those involving directional and other information of similar complexity, should be referred elsewhere. A more detailed breakdown is given in Table 4, and an analysis of at- 
TABLE 4

MANAgEment Attrtudes toward Information Service Provided In the Circulation Department $(\mathrm{N}=102)$

A A service department in which the principal objectives embrace both technical functions and information service.

B A service department in which the technical functions are of primary importance. It also, however, has a significant information service role although in-depth queries are usually referred elsewhere.

C The same as above, only the information service function although recognized is more incidental than described in the preceding option.

D Although service oriented, this department is primarily concerned with technical functions. Virtually all queries, other than those involving directional and other information of similar complexity, are referred elsewhere.

\begin{tabular}{|c|c|c|c|c|c|c|}
\hline \multirow[b]{2}{*}{ 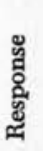 } & \multicolumn{4}{|c|}{ Library } & \multirow[b]{2}{*}{ ङ્ } & \multirow[b]{2}{*}{ 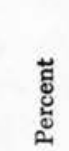 } \\
\hline & 芯 & 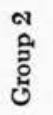 & 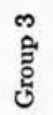 & 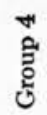 & & \\
\hline A & 1 & 1 & 5 & 2 & 9 & 8.2 \\
\hline B & 5 & 7 & 2 & 1 & 15 & 14.7 \\
\hline C & 3 & 9 & 6 & 2 & 20 & 19.6 \\
\hline D & 13 & 23 & 13 & $\overline{9}$ & 58 & 56.9 \\
\hline
\end{tabular}

titudes toward specific functions is given in Table 5. Administrators responding to this study were generally opposed to including interlibrary loan, library instruction/orientation, assistance to readers at the card catalog, and any special role in book selection within the circulation department. They favored including the reserve function and inventory. There was no major dif- ference in attitude between libraries in which the circulation department had or had not been subjected to systems analysis. Thus, library administrators at the present time are clearly in favor of a restricted and largely technical role for the circulation department. In general their preference is parallel to and often stronger than the organizational reality in the libraries they administer.

\section{SUMMARY}

This study confirms that the circulation department has evolved into a unit primarily concerned with the technical functions of physical dissemination and control of library collections. Despite the lack of functions requiring the specific assignment of professional librarians, such personnel are still widely employed in this area.

The widespread use of professional librarians in circulation work poses questions for the profession as well as for the individual library. The results of the study appear to leave only the following open as possible justification for such assignment: (1) the departmental role in policy-making, (2) the planning of routines and automation, and (3) supervisory reasons. Regarding the first, the importance of circulation policy far transcends both the department and often the library itself, and it is arguable that the formulation of such policy ought also to transcend the

TABLE 5

MANAgEMENT AtTitudes toward the Appropriateness of INCLUding Various Functions within Circulation Services $(N=103)$

\begin{tabular}{|c|c|c|c|c|c|c|}
\hline \multicolumn{7}{|c|}{$\begin{array}{l}\text { Are the following appropriate functions for the central circulation department of } \\
\text { a major university library }\end{array}$} \\
\hline Function & \multicolumn{2}{|c|}{ No } & \multicolumn{2}{|c|}{ Yes } & \multicolumn{2}{|c|}{ No Opinion } \\
\hline Interlibrary loan & 52 & 50 & 38 & 37 & 13 & 13 \\
\hline Reserve books & 14 & 1 & 83 & 8 & 6 & 6 \\
\hline Library instruction/orientation & 65 & 63 & 22 & 21 & 16 & 16 \\
\hline $\begin{array}{l}\text { Assistance of readers at the } \\
\text { card catalog }\end{array}$ & 65 & 63 & 25 & 24 & 13 & 13 \\
\hline Taking of inventory & 27 & 26 & 67 & 65 & 9 & 9 \\
\hline Special role in book selection & 52 & 50 & 35 & 34 & 16 & 16 \\
\hline
\end{tabular}


department and its myriad technical considerations. There is, in fact, no reason why such policy should originate within the circulation department. The planning of routines constitutes at best a temporary need and, once again, can be separated from the department with appropriate communication and consultation. Supervisory reasons, however, give rise to the most debate.

Some intermittent supervision is required for nonprofessionals engaged in circulation work. Yet these questions can still be raised: Can this just as readily be provided from outside the department through direct relationship with the director of reader services, assistant/ associate director, or other general supervisory position? If a professional is assigned to this department on a fulltime basis, will most of the work engaged in be professional in nature? If this is initially the case, will the individual continue to function on a professional level over a period of years? In the absence of professional functions requiring specific assignment, is profes- sional supportive staff ever justified? Given well-codified circulation policy and written manuals of procedure, are the supervisory skills required more likely to be found in a professional librarian than in an intelligent subprofessional with organizational ability? These decisions must rest with the individual library, but they demand consideration.

No longer, of course, is there a question of professionals being unavailable. Williams, writing in 1945, expressed fear that the use of professionals far less than professional work, quite aside from availability, tarnished the concept of librarians as professionals. It created a "vicious circle or descending spiral" in which low grade work discouraged the recruitment of quality manpower which, in turn, helped to insure continued low-grade work and low wages. ${ }^{10} \mathrm{Li}$ brarianship as a profession is probably better off today in most respects than in 1945 , but the concern is still a highly legitimate one, particularly when employment in highly visible positions is involved.

\section{REFERENCES}

1. American Library Association, Survey of Libraries in the United States (Chicago: American Library Association, 1926).

2. Charles Harvey Brown and H. G. Bousfield, Circulation Work in College and University Libraries (Chicago: American Library Association, 1933), p.34.

3. Donald Coney, Library Journal 58:494-95 (1 June 1933).

4. Mary Lee Bundy and Paul Wasserman, The Academic Library Administrator and His Situation (Washington, D.C.: U.S. Office of Education, Bureau of Research, 1970, ED 050796 ), p.49.

5. American Library Association, Board of Personnel Administration, Subcommittee on Analysis of Library Duties, Descriptive List of Professional and Non-Professional Duties in Libraries, Preliminary Draft (Chicago: American Library Association, 1948), p.52.

6. Donald Coney, "Scientific Management and University Libraries," in Management Problems, ed. by G. T. Schwenning (Chapel Hill: University of North Carolina Press,
1930), p.160-98; Paul Howard, "The Functions of Library Management," Library Quarterly 10:313-49 (July 1940); Henri Fayol, General and Industrial Management (London: Pitman, 1949), p.20; James D. Mooney and Alan C. Reiley, The Principles of Organization (New York: Harper, 1939), chap. 4; Ralph C. Davis, Fundamentals of Top Management (New York: Harper, 1951), p.213.

7. Earned Degrees Conferred: Higher Education, Part A: Summary Data, 1966/1967 (Washington, D.C.: U.S. Office of Education, 1969).

8. These had other than reserves, periodicals, and special forms of materials circulated from positions physically and administratively separate from a central point.

9. Mooney and Reiley, Principles of Organization, p.26.

10. Edwin E. Williams, "Who Does What: Unprofessional Personnel Policies," CRL 6: 304 (Sept. 1945). 